\title{
PRIEŠ LAIKĄ PAGIMDŽIUSIŲ MOTERŲ PATIRTYS
}

\author{
Alina Vaškelyte் $\dot{1}^{1,2}$, Herta Naujokaitè ${ }^{2}$ \\ ${ }^{1}$ Kauno kolegijos Medicinos fakulteto Slaugos katedra, \\ ${ }^{2}$ Lietuvos sveikatos mokslu universiteto Slangos fakulteto Slaugos ir rüpybos katedra
}

Raktažodžiai: priešlaikinis gimdymas, neišnešiotas naujagimis, mamų patirtys.

\section{Santrauka}

Vaiko gimimas pripažįstamas kaip išskirtinis ir gyvenimą keičiantis ivvykis, reikalaujantis jautrios paramos ir pagalbos, turintis itakos trumpalaikei ir ilgalaikei šeimos gerovei. Šeima susikuria būsimo naujagimio paveikslą dar jam negimus. Neišnešioto naujagimio gimimas neatitinka tėvų lūkesčių, todèl šeimos patiria daug emocinių išgyvenimų ir turi taikytis prie naujų aplinkybių. Šeima baiminasi, kad vaiko būklè nepasunkètų, abejoja savo gebejjimais rūpintis neišnešiotu naujagimiu bei ịveikti kasdien vis naujas problemas. Siekiant atskleisti prieš laiką pagimdžiusių moterų patirtis, atliktas kokybinis tyrimas Lietuvos ligoninès Neonatologijos klinikoje. Tyrime dalyvavo penkios šioje ligonineje pagimdžiusios moterys, kurių naujagimiai buvo gydomi Naujagimių ligų skyriuje ne mažiau nei dvi savaites. Atliekant tyrimą, taikytas pusiau struktūruoto interviu metodas. Tyrimo radiniai atskleidè, kad prieš laiką pagimdžiusių moterų néštumas nesiskyrẻ nuo ịprastinès néštumo eigos, todèl staiga pasirodę priešlaikinio gimdymo požymiai tyrimo dalyvėms kèlè baimę, šoką, nežinomybę, mamos išgyveno planuotos néštumo patirties praradimą, jautėsi nepasiruošusios gimdymui ir motinystei. Dèl staiga prasidejjusio priešlaikinio gimdymo, moterims teko keisti gimdymo planus, o naujagimio atskyrimas nuo mamos iškart po gimimo turejjo įtakos ankstyvai motinystès patirčiai - mamos prarado motinystès vaidmenį, gimęs neišnešiotas naujagimis neatitiko vaizduoteje susikurto naujagimio paveikslo, tačiau sveikatos priežiūros specialistų emocinè parama ir pagalba padejo mamoms priimti naujagimị ir juo pasirūpinti.

\section{Ivadas}

Priešlaikinis gimdymas - tai gimdymas nuo $22(+0)$ iki 36(+6) něštumo savaitès. Kai tikslus nèštumo laikas nežinomas, laikoma, kad gimdymas yra priešlaikinis, jei naujagimis sveria $\geq 500 \mathrm{~g}$ [1]. Pasaulio sveikatos organizacijos (PSO) duomenimis, pasaulyje vienas naujagimis iš 10 gimsta per anksti, tai sudaro maždaug 15 milijonų naujagimių kiekvienais metais [2]. 2018 metais Lietuvoje iš 26159 naujagimiu 1429 gimè neišnešioti, tai sudare 5,5 proc. visu gyvų gimusių naujagimių [3]. Priešlaikinių gimdymų skaičiaus didėjimas susijęs su didejjančiu vidutiniu motinos amžiumi, pagalbinio apvaisinimo technologijų naudojimu, kuris susijęs su daugiavaisiu nèštumu $[4,5]$.

Lietuvoje, kaip ir pasaulyje, priešlaikinis gimdymas sukelia daugiausia naujagimių mirčių ir kūdikių sergamumo atvejų, todèl tai yra viena iš didžiausių akušerijos problemų [4]. Neišnešiotų naujagimių mirštamumas yra 20-30 kartų didesnis, nei išnešiotų ir sudaro 80 proc. viso naujagimių mirtingumo [2]. Naujagimių sergamumo ir mirštamumo rizika mažeja, ilgejjant něštumo laikui. Ekonomiškai išsivysčiusiose šalyse neišnešiotų naujagimių išgyvenamumas didejja, tačiau, neišnešiotumas gali turèti reikšmès vaiko raidai, sveikatai ir gyvenimo kokybei [5]. Šeimoms, susilaukusioms neišnešioto naujagimio, kyla daug klausimų, trūksta slaugos žinių ir ịgudžių. Dèl patiriamų išgyvenimų šioms šeimoms reikalinga ne tik sveikatos priežiūros specialistų medicininè pagalba, bet ir emocinè parama [6]. Atliekami tyrimai dažniausiai nagrinèja priešlaikinio gimdymo įtaką naujagimio vystymuisi $[4,5]$ ir mažai skiria dèmesio, kaip priešlaikinis gimdymas veikia motinos gerovę. Mūsų atliktas tyrimas padès atskleisti, ką išgyvena šeimos, susilaukusios neišnešioto naujagimio, kokie tèvų poreikiai ir kokia jiems reikalinga sveikatos priežiūros specialistų pagalba. Tyrimo radiniai leis geriau suprasti prieš laiką pagimdžiusių moterų problemas ir padès sveikatos priežiūros specialistams, tarp jų ir akušeriams, planuoti pagalbą ir imtis tinkamų veiksmų, padedant tèvams valdyti emocijas ir siekti palankios motinystès.

Tikslas - atskleisti prieš laiką pagimdžiusių moterų patirtis.

\section{Tyrimo medžiaga ir metodai}

Tyrimas buvo vykdomas 2019-2020 m. Lietuvos ligoninès Neonatologijos klinikų Naujagimių ligų skyriuje (NLS). 
Dalyvauti tyrime tikslinès atrankos būdu pasirinktos prieš laiką gimdžiusios moterys, kurių naujagimiai gimė gyvi, neturintys ịgimtų anomalijų ir buvo gydomi NLS ne mažiau nei 2 savaites. Tyrimo duomenys rinkti pusiau struktūruoto interviu metodu, naudojant iš anksto numatytus vedamuosius bei patikslinamuosius klausimus. Tyrime dalyvavo penkios mamos. Trumpa informančių charakteristika pateikiama 1 lentelèje. Gavus informančių sutikimą, interviu buvo įrašomas i diktofoną, vèliau tekstas iššifruojamas ir užrašomas. Siekiant geriau suprasti kontekstą, iššifruotas tekstas keletą kartų atidžiai perskaitytas. Tekste išskirti reikšminiai kodai sujungti ị potemes, o potemès ị temas. Vidutinè interviu trukmè buvo 47 minutès. Ilgiausias truko 60, trumpiausias - 34 minutes. Visoms tyrimo dalyvėms paaiškinta apie konfidencialumo užtikrinimą, informuotos, kad jų vardai bus pakeisti. Tyrimui atlikti gautas Lietuvos sveikatos mokslų universiteto Bioetikos centro pritarimas Nr. BEC-AK(B)-26.

Visos tyrime sutikusios dalyvauti moterys buvo ištekèjusios, dvi turejjo po vieną vaiką, trims tai buvo pirmasis gimdymas.

\section{Tyrimo rezultatai}

Interviu duomenų analizè atskleidè tris pagrindines temas: 1) „Niekada negalvoji, kad tavo bus ankstukas“; 2) Netiketas gimdymas; 3) „Ne tokią motinystę mamos įsivaizduoja“.

Niekada negalvoji, kad tavo bus ankstukas. Dauguma tyrimo dalyvių, kalbėdamos apie néštumo laikotarpi, pasakojo, kad jis buvo lengvas, moterys nejaute jokių simptomų, kad kažkas gali būti ne taip: „Viskas buvo taip, kaip turi būti, kaip aprašyta knygose ir kaip medikai norètų, kad būtų. Tai visas néštumas viskas tvarkoj, su vaiku, svorio priaugimas, ta prasme, absoliučiai visi tyrimai, viskas buvo geri. <..> Tai yra, jeigu šnekant apie pati nèštumą, tai jisai buvo tobulas." (Simona). Interviu metu surinkta informacija patvirtino ankstesnius kitų mokslinių tyrimų rezultatus [4,5], rodančius, kad viena iš dažniausiai minimų priešlaikinio gimdymo priežasčių buvo priešlaikinis neišnešioto vaisiaus dangalų plyšimas: „Pirmadieni pradejo nubèginèti vandenys ir antradienį jau išvažiavom gimdyti. Tai tas dvi dienas, kai atsistoji kiekvieną kartą ir jauti, kad bėga vandenys, man tai buvo neramu baisiai." (Ieva).

Pirminè reakcija ị priešlaikinị gimdymą tyrimo dalyvèms dažniausiai pasireiške šoku, fakto neigimu, per dideliu susirūpinimu, pasitikèjimo savimi praradimu, bejègiškumu. D. Gibbs (2015) teigia, kad baimé yra normali reakcija ị nežinomybę. Daugelis tėvų neturi priešlaikinio gimdymo patirties, todèl nerimauja dèl savo naujagimio, jo sunkių ligų, negalios ar net mirties galimybès. Tèvai gali net suabejoti savo sugebejjimais rūpintis neišnešiotu naujagimiu [7]. Nei viena tyrimo dalyvė nesitikèjo priešlaikinio gimdymo, todèl normalaus nèštumo praradimas atėmé galimybę patirti planuotą nèštumo ir gimdymo patirti bei mamos lūkesčius po gimimo iš karto auginti naujagimį namuose: „Nu viskas atrodo, gyvenimas apsiverčia aukštyn kojom, tu gyvenai visai kitokị gyvenimą, tu planavai visai kitaip, kaip tu išnešiosi, kaip tu sutiksi šventes, kur tu būsi, kaip įrenginèsim savo naujus namus, koks bus vaiko kambarys, o čia labai greitai ir visos svajonès dingsta. Buvo sunku patikèti tuo, kas vyksta, tiksliau, ir nenorejau tuo tikèti.“ (Rūta).

Interviu metu buvo siekiama išsiaiškinti, ar mamos něštumo metu nori gauti daugiau informacijos apie priešlaikinị gimdymą. N. Gaucher su bendraautoriais (2018) atliktame tyrime teigiama, kad su nèštumu susijusių seminarų lankymas moterims, kurioms nėštumo metu grèsė priešlaikinis gimdymas, padeda psichologiškai pasiruošti galimai gimdymo baigčiai [8], tačiau tyrime dalyvavusios moterys nèštumo metu informacijos poreikio apie priešlaikini gimdymą neišsakè: „Žinojimas tikrai nepadès emociškai, kai tai ịvyks. Tu gali nežinoti, bet tas jausmas, kai tu pagimdai likus pusei néštumo, aš kad ir būčiau žinojus, tai manęs negelbètų, tai ką man tenka patirti nuo pat pradžių.“ (Rūta). Galima daryti prielaidą, kad moterys nèštumo metu nesidomi priešlaikinio gimdymo rizika, jos tikisi sulaukti gimdymo termino, todèl pasirodę priešlaikinio gimdymo požymiai sukèlẻ šoką, baimę dèl gimdymo baigties ir naujagimio sveikatos būklès.

1 lentelè. Tyrimo dalyvių charakteristikos

\begin{tabular}{|c|c|c|c|c|c|c|}
\hline \multirow{2}{*}{$\begin{array}{l}\text { Suteik- } \\
\text { tas var- } \\
\text { das }\end{array}$} & \multirow[b]{2}{*}{$\begin{array}{l}\text { Am- } \\
\text { žius }\end{array}$} & \multirow[b]{2}{*}{$\begin{array}{l}\text { Išsilavi- } \\
\text { nimas }\end{array}$} & \multirow[b]{2}{*}{$\begin{array}{l}\text { Šeiminè } \\
\text { padètis }\end{array}$} & \multicolumn{2}{|c|}{ Naujagimio } & \multirow{2}{*}{$\begin{array}{c}\text { Gydymo } \\
\text { trukmè } \\
\text { NLS }\end{array}$} \\
\hline & & & & $\begin{array}{l}\text { gimimo } \\
\text { amžius } \\
\text { (sav.) }\end{array}$ & $\begin{array}{l}\text { svo- } \\
\text { ris } \\
\text { (g) }\end{array}$ & \\
\hline Lina & 20 & vidurinis & ištekèjusi & 31 & 1584 & $\begin{array}{c}5 \text { sav. ir } \\
2 \mathrm{~d} .\end{array}$ \\
\hline Simona & 39 & $\begin{array}{c}\text { aukš- } \\
\text { tasis } \\
\text { universi- } \\
\text { tetinis }\end{array}$ & ištekèjusi & 31 & 1650 & $\begin{array}{c}2 \text { sav. ir } \\
1 \mathrm{~d} .\end{array}$ \\
\hline Nijolè & 36 & $\begin{array}{c}\text { aukš- } \\
\text { tasis } \\
\text { neuni- } \\
\text { versite- } \\
\text { tinis } \\
\end{array}$ & ištekèjusi & 29 & 1280 & $\begin{array}{c}3 \text { sav. ir } \\
6 \mathrm{~d} .\end{array}$ \\
\hline Rūta & 27 & $\begin{array}{c}\text { aukštes- } \\
\text { nysis }\end{array}$ & ištekèjusi & 23 & 630 & $\begin{array}{c}13 \text { sav. ir } \\
2 \mathrm{~d} .\end{array}$ \\
\hline Ieva & 32 & $\begin{array}{c}\text { aukš- } \\
\text { tasis } \\
\text { universi- } \\
\text { tetinis }\end{array}$ & ištekèjusi & 26 & 1110 & $\begin{array}{c}2 \text { sav. ir } \\
4 \mathrm{~d} .\end{array}$ \\
\hline
\end{tabular}


Netikėtas gimdymas. Atlikus interviu analizę pastebėta, kad neišnešiotų naujagimių mamos nesijautẻ pasiruošusios gimdymui, tačiau išgyvenusios visas neigiamas emocijas, jos susitaikè su situacija: „Neturi tokio įsivaizdavimo, tu nesiruoši gimdymui, tu nieko neturi, nei tų pačiu drabužèlių ar kažko susipirkęs tokiam laikui, tai toks vis tiek būna šokas, pačio pirminio fakto, paskui jau kažkaip susitaikai su ta mintim, kad viskas bus gerai, turi būti gerai, tikèjimas.“ (Ieva). F. Rosati su bendraautoriais (2019) pastebejo, kad neišnešiotų kūdikių motinoms pasireiškia ūmi reakcija i priešlaikinį gimdymą, tyrèjai aprašè krizès laikotarpì, kuriuo motinai, nesugebančiai tinkamai reaguoti ị situaciją, būdingi psichiniai ir elgesio sutrikimai. Noredamos ịveikti šią krizę, moterys turi stengtis priimti realybę ir neigiamas emocijas išreikšti, o ne neigti, nes tik tada susitaikoma su ìvykusia situacija [9]. Kai kurioms mamoms susitaikyti su ìvykusia situacija padejo pasitikejjimas medicina ir sveikatos priežiūros specialistais: „Pasitikẻjimas didžiausias yra gydytojais, kai matai, kad turim priežiūrą, specialistus puikius, tai kažkaip mažiau ir tos baimès." (Lina).

Pasak D. Gibbs (2015), šiandien daugelis porų planuoja, kas dalyvaus gimdyme, kaip atrodys aplinka, kaip jie valdys gimdymo procesą ir kokio nori medicininio ịsikišimo. Kai kurie rašo išsamius gimdymo planus, ketindami perduoti savo norus priežiūros paslaugų teikèjams. Deja, dèl neišnešioto ar komplikuoto gimdymo gali reikèti staigių, nenumatytų savo planų pakeitimų [7]. Dažniausiai gimdymas tyrimo dalyvèms prasidejo staiga ir nevyko taip, kaip buvo planuotas, todèl dauguma moterų ir jų partnerių vèliau apgailestavo, kad prarado planuotą gimdymo patirtį: „Tai aš net vyrui nepaskambinau, paskambinau jau gimdykloj po visko, kad aš jau pagimdžiau, nes nebuvo kada. Tai ir vyrui, ir man buvo gaila, nes pirmame gimdyme tai dalyvavo jis, o ị šitą jau nesuspejjo.“(Ieva).

Daugelị neišnešiotų naujagimių iškart po gimimo medikams tenka atskirti nuo mamos ir teikti pagalbą. M. Spinelli (2016) su bendraautoriais atliko tyrimą, kuriame nustate, jog kai naujagimis gydomas Naujagimių intensyviosios terapijos skyriuje (NITS), sunku užmegzti ryšį tarp mamos ir naujagimio, todèl mamos nesijaučia mamomis, nors ir žino, kad tokios yra, tačiau visą rūpinimąsi naujagimiu perima sveikatos priežiūros specialistai ir medicininè ịranga, kuri palaiko naujagimio gyvybę [10]. Tyrimo dalyvès, kalbėdamos apie jausmus naujagimiui, neslëpè, kad patyrè nežinomybę, nes iškart po gimimo naujagimis buvo atskirtas. Naujagimiu rūpinosi medikai ir slaugytojos, todèl naujagimis tapo tarsi nebe mamų, jos neturejjo galimybès ankstyvam oda prie odos kontaktui, dažnai net nepamate, kaip atrodo naujagimis, neturejjo informacijos apie jo sveikatos būklę: ,Aš kai pagimdžiau, jo net nemačiau, buvo keistas jausmas, nes tas vaikas, kuris ką tik buvo manyje dabar yra svetimose rankose, bet aišku, tu supranti, kad dabar turi būti taip, kad dabar medikams reikia kovoti už jo gyvybę, o mes mamos spèsim visada..." (Rūta). Keletas tyrimo dalyviu pasakojo, kad labai laukè informacijos apie naujagimio sveikatos būklę, todèl bendravimas su personalu padejo moterims nusiraminti: „Tai tas informacijos suteikimas labai nuramino, nes tu guli palatoj ir nematai savo vaiko, tai labai svarbu, kad reikiamu momentu kažkas ateitų ir papasakotų kaip kas." (Simona). Šio tyrimo radiniai parode, kad netiketos gimdymo patirtys, kurios neatitinka moterų lūkesčių, dažnai sukelia nusivylimą gimdymu ir gali turèti įtakos motinos santykiams su naujagimiu.

Ne tokią motinystę mamos ịsivaizduoja. Per néštumo laikotarpị tèvai buvo susikūrę savo naujagimio ịvaizdị. Daugeliui tèvų tai buvo sveikas, visavertis kūdikis, todèl pirmą kartą pamatę neišnešiotą naujagimį, tèvai prarado tai, ko tikejosi. Dauguma tyrimo dalyvių pasakojo, kad šokas buvo pirmoji reakcija, pamačius naujagimį NITS: „Pirmą kartą irgi neblogas šokas, nes kaip sakiau, galvojau išnešiosiu, ịsivaizdavau tą kūdikį tokị na reklaminị, pilną svorio, pūstais žandukais, o čia pamatai kauliukai ir oda, be proto mažas, aišku, yra ir dar mažesnių, aišku, keistas jausmas." (Nijolè). K. Loewenstein (2019) su bendraautoriais atliktas tyrimas parode, jog pirmoji motinos reakcija ị neišnešiotą naujagimi NITS yra kaip lankytojo, svetimo ar nepažistamo asmens, o per pirmąsias savaites motina jaučiasi ambivalentiška dèl savo santykių su naujagimiu [6]. Apie tai kalbejo ir tyrime dalyvavusios mamos: „Nuejimas prie to vaiko ir pastovèjimas, kas tas tris valandas, nèra to tokio ryšio." (Nijolè).

M. Spinelli su bendraautoriais (2016) teigia, kad moterys nèštumo metu susikuria naujagimio mamos vaidmeni, tačiau, susidūrusios su realybe, jos praranda tai, ko tikejosi něštumo pradžioje ir jaučia naujagimio priežiūros ribojimą [10]. Tyrimo dalyvès, kurių naujagimiai iškart po gimimo buvo atskirti, pasakojo, kad jos nesijaute naujagimių mamomis, nes tuo metu negalèjo pasirūpinti vaiku, visa tai atliko slaugytojos ir medikai: „Kai pagimdžiau, tai, nu, mes nei viena nesijaučiame mamos, kai gimsta tokie mažiukai, kai jie auga inkubatoriuose, kai tu gali nueiti tiktai pasižiūretti, nu tai yra slauga, tai nèra mama, tai yra tiktai slaugytoja, auklè.“ (Rūta).

Išanalizavus interviu duomenis paaiškejjo, kad dauguma mamų, pamačiusios naujagimį, bijojo prie jo prisiliesti, tačiau pirmasis prisilietimas sukèlè labai daug emocijų, o mamų ịtraukimas ị naujagimio priežiūrą skatino pasitenkinimą motinyste: „Labai mažas, jis visas toks gležnutis, kauliukai ir oda realiai, ten nieko daugiau nèra ir ta oda tokia raudona. Aišku iš karto klausè, gal norit paliesti, tai sakau ne dabar, kažkaip nedrąsu buvo, bet turbūt kitą dieną sakiau gerai, jau ten pradejom mokintis keisti pampersus inkubatoriuje, tai 
buvo labai smagu, nes jauti vaiką arčiau, jauti, kad vis tiek kitaip pakeisi nei seselé“. (Ieva). Atlikti moksliniai tyrimai rodo, kad mamų įtraukimas ị naujagimio priežiūrą, dalinimasis informacija skatina mamos pasitikejimą, mažina nerimą ir formuoja artimesnị ryši su naujagimiu $[6,10]$.

F. Rosati su bendraautoriais (2019), aprašiusi prieš laiką pagimdžiusių mamų patirtis, teigia, kad neišnešioto naujagimio gimimas ir hospitalizacija ị NITS, jo atskyrimas nuo šeimos sukelia tèvams stresą, todèl pagalba neišnešiotam naujagimiui turi būti neatskiriama nuo pagalbos jo šeimai šiuo laikotarpiu ịveikti sunkumus [9]. Tyrime dalyvavusios mamos kalbėjo apie emocinę paramą, kuri būtina norint susitaikyti su situacija. Kaip pagrindinị paramos šaltinị tyrimo dalyvè įvardijo gebejjimą dalintis patirtimi su kitais tėvais, atsidūrusiais tokioje pačioje situacijoje, nes bendravimas su tais, kurie suprato, ką tèvai išgyveno, padejo valdyti savo jausmus ir prisitaikyti prie gyvenimo pokyčių: „Vienintelè pagalba tokioms mamoms yra kitos mamos, tai yra vienintelè pagalba, nei vyras, nei tévai, nei draugai, bet vienintelè pagalba yra tos mamos, kurios tą patị išgyveno." (Ieva).

Pasak K. Loewenstein (2019), būti mama NITS yra individualus raidos procesas, kurio metu nuo buvimo antraeiliu naujagimio prižiūrètoju pereinama prie savarankiško rūpinimosi naujagimiu. Vis dèlto, ankstesnè patirtis sukelia mamoms prieštaringus jausmus, tokius kaip baimę ir palengvèjimą, laimę ir atsakomybę. Mamos vèl turi priimti pasikeitusị savo vaidmenį, kuris reiškia „tapimas tikra mama“ [6]. Tyrime dalyvavusios mamos džiaugèsi, kad galès būti kartu su naujagimiu, tačiau baiminosi, ar galès pasirūpinti jo sveikatos būkle taip, kaip rūpinasi medikai: „Aišku, reanimacijoj buvo ramu, kad žinai visą parą turi priežiūrą ir jei kas nors, tikrai gydytoja atlèks ir bus sutvarkyta. O kai palatoj tu matai, kad ten skaičiai kažkokie, bėgi pas seselę tada." (Lina).

Buvimas kartu su naujagimiu tyrimo dalyvėms kèlè daug džiaugsmo, stiprejjo emocinis ryšys tarp naujagimio ir mamos, didejjo laktacija. F. Rosati (2019) teigia, jog ilgą laiką išbuvusios ligonineje mamos nori privatumo, joms trūksta artimujų, namų aplinkos, nori pabūti su savo kūdikiu privačioje erdvejje [9]. Tyrimo dalyvès ieškojo namų aplinkai artimesnès vietos, todèl rinkosi privačias palatas. Naujagimio išvaizdos ir sveikatos pokyčiai teikè mamoms optimizmo ir teigiamų emocijų: „Sakau, kiekvienu laiduku mažiau, paskui tik zonduką palieka, pradeda valgyti iš buteliuko iš krūties tai išvis, tas duoda optimizmo, kad eina viskas i prieki, matai, kad svorio to priauga, nebėra tokia mažytè, tas turbūt labai svarbu mamom, tą pokytị pamatyti, kuo tu greičiau pamatai, to optimizmo atsiranda kažkokio.“ (Nijolè).

Apibendrinant galima teigti, kad mamos, kurių naujagimiai buvo gydomi NITS, prarado motinystès vaidmeni, tačiau bendravimas su kitais tẻvais, esančiais tokioje pačioje situacijoje, ankstyvas mamos įtraukimas ị naujagimio priežiūrą padejjo valdyti neigiamas emocijas ir patirti motinos pasitenkinimą.

\section{Išvados}

1. Tyrimo dalyvių nèštumas dažniausiai buvo sklandus, moterys tikèjosi sulaukti gimdymo termino, todèl priešlaikinio gimdymo požymiai sukėlè šoką, baimę, nežinomybę; mamos išgyveno planuotos nèštumo patirties praradimą, jautėsi nepasiruošusios gimdymui ir motinystei.

2. Dažniausiai priešlaikinis gimdymas ịvyko staiga, todèl moterims teko keisti savo gimdymo planus. Gimdymas nebuvo fiziškai sunkus, bet naujagimio atskyrimas nuo mamos iškart po gimimo turèjo įtakos ankstyvai motinystès patirčiai.

3. Pogimdyminiu laikotarpiu mamos prarado motinystes vaidmenį, gimęs neišnešiotas naujagimis neatitiko vaizduoteje susikurto naujagimio paveikslo, tačiau sveikatos priežiūros specialistų emocinè parama ir pagalba padejo mamoms priimti naujagimị ir juo pasirūpinti.

\section{Literatūra}

1. Autorių kolektyvas. Priešlaikinis gimdymas. Metodika. LR SAM, 2014:61.

https://sam.lrv.lt/uploads/sam/documents/files/Veiklos_sritys/ Programos_ir_projektai/Sveicarijos_parama/Akuserines $\% 20$ metodikos/Prieslaikinis\%20gimdymas.pdf

2. Preterm birth. WHO recommendations on interventions to improve preterm birth outcomes. WHO 2015:98. https:// www.who.int/en/news-room/fact-sheets/detail/preterm-birth

3. Higienos instituto Sveikatos informacijos centras. Gimimu medicininiai duomenys 2018. http://hi.lt/lt/gimimu-medicininiai-duomenys.html

4. Purisch SE, Gyamfi-Bannerman C. Epidemiology of preterm birth. Sem Peri 2017;41(7): 387-391.

https://doi.org/10.1053/j.semperi.2017.07.009

5. Frey HA, Klebanoff MA. The epidemiology, etiology, and costs of preterm birth. Sem Fetal Neon Med J. 2016;21(2):68-73.

https://doi.org/10.1016/j.siny.2015.12.011

6. Loewenstein K, Barroso J, Phillips S. The experiences of parents in the neonatal intensive care unit. J Peri Neon Nurs 2019;33(4):340-349.

https://doi.org/10.1097/JPN.0000000000000436

7. Gibbs D, Boshoff K, Stanley M. Becoming the parent of a preterm infant: a meta-ethnographic synthesis. Br J Occup Ther 2015;78(8):475-487.

https://doi.org/10.1177/0308022615586799

8. Gaucher N, Nadeau S, Barbier A, Payot A. Antenatal consultations for preterm labour: how are future mothers reassured? Arch Dis Child Fetal Neonatal Ed 2018; 103 (1): 36-42. 
https://doi.org/10.1136/archdischild-2016-312448

9. Rosati F, Gasparrini E, Gaetti MT. The experience of a mother in the situation of a preterm birth. Clin Moth Child Health 2019; 16 (3).

https://www.longdom.org/open-access/the-experience-of-amother-in-the-situation-of-a-preterm-birth-25923.html

10. Spinelli M, Frigerio A, Montali L, Fasolo M, Spada MS, Mangili G. "I still have difficulties feeling like a mother": the transition to motherhood of preterm infants mothers. Psych Health 2016; 31(2):184-204.

https://doi.org/10.1080/08870446.2015.1088015

\section{EXPERIENCES OF PREMATURE NEWBORNS MOTHERS A. Vaškelytė, H. Naujokaitė}

Keywords: premature birth, premature newborn, mothers' experiences.

Summary

The birth of a child is recognized as an exceptional and lifechanging event that requires sensitive support and assistance, affecting the short-term and long-term well-being of the whole family. The birth of a premature newborn does not meet the expectations of parents, as a result families face endless emotional experiences and are forced to adapt to new circumstances. The family is accompanied by the fear that the child's condition will not get worse, doubts about their ability to take care of the premature baby and cope with the challenges that arise on a daily basis.

To reveal women experiences of giving preterm birth a qualitative study was performed at the Neonatology Clinic of one of the Lithuanian hospitals. The study involved five women who gave birth at this hospital and whose newborns were treated in the Neonatal Diseases Unit for at least two weeks. Semi-structured interview method was applied in the study.

The findings of the study revealed that the pregnancy of women who gave birth prematurely did not differ from the normal pregnancy, so the sudden signs of preterm birth caused fear, shock, uncertainty, mothers experienced a "loss" of planned pregnancy experience, and felt unprepared for childbirth and motherhood. Preterm birth usually occurred suddenly, forcing women to change their birth plans and a newborn separation from the mother immediately after birth had an impact on early maternal experience - mothers lost the role of motherhood, the premature newborn did not match the imaginary image of the newborn, but emotional support and help from health care professionals helped the mothers to receive and care for the newborn.

Correspondence to: alina.vask@gmail.com

Gauta 2020-08-26 